\title{
Chemical and Mineralogical Characterization of Ghanaian Foundry Slags
}

\author{
A. Andrews ${ }^{1 *}$, E. Gikunoo ${ }^{1}$, L. Ofosu-Mensah ${ }^{1}$, H. Tofah ${ }^{1}$, S. Bansah ${ }^{2}$ \\ ${ }^{1}$ Department of Materials Engineering, Kwame Nkrumah University of Science and Technology, \\ Kumasi-Ghana \\ ${ }^{2}$ Department of Geological Engineering, Kwame Nkrumah University of Science and Technology, \\ Kumasi-Ghana
}

*Corresponding Author: anthonydrews@gmail.com

\begin{abstract}
The application of ferrous slags as aggregate, road bed materials, soil fertility conditioner and as clinker materials depend on their chemical and mineralogical characteristics. In order to assess the possibilities of using ferrous slags generated in Ghana, selected slag samples from some foundries have been characterized. A total of six bulk samples were collected from three different foundry shops to determine their chemical and mineralogical composition. The slag samples showed varied chemical and mineralogical characteristics. Differences are as a result of the differences in furnace charge, operation temperatures, grades of refractory furnace lining and melting additives. Calcium oxide ( $\mathrm{CaO})$ contents observed in all investigated samples were in combined form (i.e. not free CaO). The low amounts of calcium oxide in the slag samples limit their applications in the area of cement/aggregate production. Even though slags were found to be alkaline, for these slags to effectively neutralize the acidity of soil and improve its fertility, components such as $\mathrm{CaO}, \mathrm{SiO}_{2}, \mathrm{MgO}$ and $\mathrm{FeO}$ in the slag must be improved. However, these slags could be used as road bed materials.
\end{abstract}

Keywords: Cupola slag; Induction furnace slag; Characterization; Recycling

\section{INTRODUCTION}

In the Ghana foundry industry, only minute fraction of the wastes generated is recovered and reused. Large fraction of the waste generated are often disposed off on the factory floor. Foundry wastes generated includes waste foundry sand, slag, dust and sludge. Usually, these wastes are 
hazardous to the environment [1-3]. For instance, slag containing sulfurous leachate can result in sulfur odor and discoloration of water in poor drainage conditions [4]. Additionally, slag containing high levels of nickel can cause corrosion of iron and steel in the presence of moisture [5]. Nevertheless, slags containing negligible amount of sulfur and nickel are not ecologically harmful and therefore could be used [6]. Therefore, there is the need to properly handle foundry slag to alleviate any potential adverse effects on the environment.

Slag is a waste material (by-product) generated in purifying metals, their casting and alloying. Ferrous slags are generated from the production and castings of iron and steel. There are different types of ferrous slags, each one named from the process of which they are generated: blast furnace slag (BF) also called iron slag, basic oxygen furnace slag (BOF), electric arc furnace slag (EAF) and ladle furnace slag (LF) also called refining slag. Slag types investigated in this work are cupola furnace (CF) slag and induction furnace (IF) slags [7].

Current interviews and data collection suggest that more than 50,000 tons of ferrous slags are produced in Ghana annually. This figure will continue to rise as small and medium scale foundries spring up. Additionally, until quality scraps, energy efficient furnaces, quality refractory furnace linings and quality foundry coke are used, the amount of slag generated would increase as these parameters directly impact on slag generation and its quality [8-10]. Currently, slag produced is disposed off on the foundry site floor. However, there is a great demand for aggregate in the Civil Engineering industry in Ghana, especially in the construction of road and production of Portland cement. In other countries, such as Western Europe and in the U.S.A, blast furnace slag is widely known to serve as raw material for cement production as well as concrete manufacturing unit due to the presence of pozzolonic activity [6,11,12]. Electric arc furnace (EAF) slag cannot be used for such purposes due to its high iron content. EAF has however, found increased use as recycled aggregate in road construction [12]. Steel slag having high content of $\mathrm{CaO}$ but low levels of phosphorus and sulfur are reused as fluxing material in steel making process to replace limestone [7]. Steel slags are also being used in areas such as road construction, fertilizers and soil conditioners, and for metal recoveries. Utilizations of these slags were made possible by first knowing their physico-chemical and mineralogical properties. A proper characterization of foundry slag could effectively serve as basis for identifying possible utilization areas in Ghana. There is no literature available on the chemical and mineralogical characteristics of cupola and induction furnace slags generated in Ghana. To date, slags from these furnaces are not being used and are deposited on the site. These slags are air-cooled and are therefore crystalline [13].

In the present study an attempt has been made to determine the chemical and mineralogical composition of cupola and induction furnace slags generated by some small and medium scale foundries in Ghana. Knowledge of these is important in order to know the possible utilization areas of these by-products. 


\section{MATERIALS AND METHODS}

\subsection{Materials}

Induction furnace (IF) slag samples were obtained from Western Steel and Forging Limited located in the Accra-Tema metropolis. Cupola furnace (CF) slag samples were obtained from two small scale foundries (Horoos and Abudia foundries) located in the Kumasi metropolis. Sampling was carried out by inserting a sample rod into a slag pan as the slag was tapped. The rod was then withdrawn from the pan and allowed to cool in air. Two of such slag samples were taken after each steel production batch. Samples were crushed with a jaw crusher followed by milling to obtain powdered samples. The powdered samples were sieved with a $250 \mu \mathrm{m}$ size. Representative samples of the undersize fraction were used for further analyses. Samples A and B are representative CF slags from Horoos and Abudia foundries, respectively. Sample C is IF slag from Western Steel and Forging Limited.

\section{$2.2 \quad$ Method}

The chemical compositions of the slags were determined using X-ray fluorescence spectroscopy (XRF- Spectro X-LAB 2000). The samples were sieved and the undersize from a $180 \mu \mathrm{m}$ mesh grid obtained. $4 \mathrm{~g}$ of each representative samples were taken and mixed with equal amount of wax for 3 minutes in a homogeniser. The mixtures were compressed into circular shapes for the XRF analysis. XRF analyses were carried out in duplicate and the average results taken.

Mineralogical composition was studied at room temperature $\left(25^{\circ} \mathrm{C}\right)$ using X-ray diffractometer (Siemens D5000), operating at $40 \mathrm{kV}$ and $40 \mathrm{~mA}$, using $\mathrm{Cu} \mathrm{K \alpha}$ radiation. Samples were scanned at $15^{\circ}-70^{\circ}(2 \theta)$ and step size of $0.02^{\circ}$. Samples were then milled to pass $10 \mu \mathrm{m}$ mesh grid before scanning. The $\mathrm{pH}$ of the slag samples was determined using a $\mathrm{pH}$ meter. Ganulometric analysis (mesh grid) was carried out to determine size distribution in the slag samples investigated.

\section{RESULTS AND DISCUSSION}

\subsection{Physical Characteristics of Slags}

All samples were air cooled. Samples had blue black appearance. A typical image of the ferrous slag is shown in Figure 1. Investigated samples were alkaline with sample A having $\mathrm{pH}=8.06$, sample $\mathrm{B} \mathrm{pH}=8.20$ and sample $\mathrm{C} \mathrm{pH}=7.14$.

Figure 2 shows the ganulometric analysis of the slag samples. The differences in \% passing for the three ferrous slag samples varied slightly with sample A and sample B (copula slags) having higher \% passing than sample C. The samples investigated had particle sizes lower than $425 \mu \mathrm{m}$ with only $2 \%$ passing $75 \mu \mathrm{m}$ sieves. The grain size analysis is widely used in the classification of 
slag. The data obtained from grain size distribution curves is used in the design of filters for earth dams and to determine suitability of slag for road construction [14].

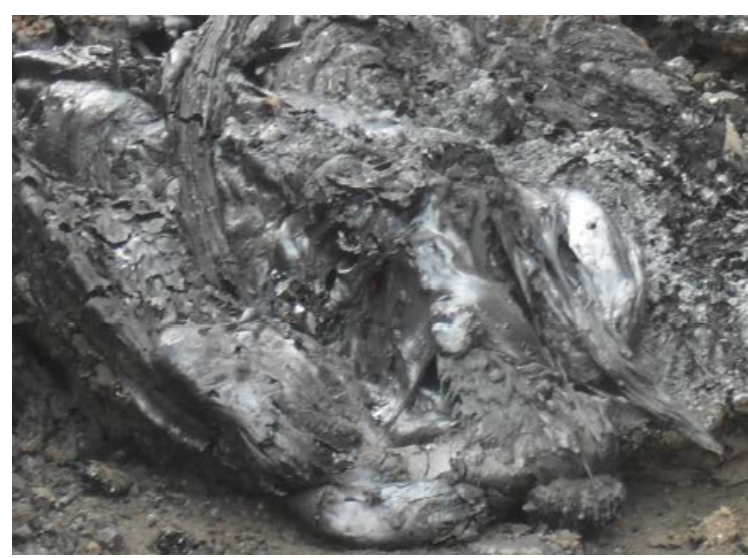

Fig. 1: Typical image of ferrous slag.

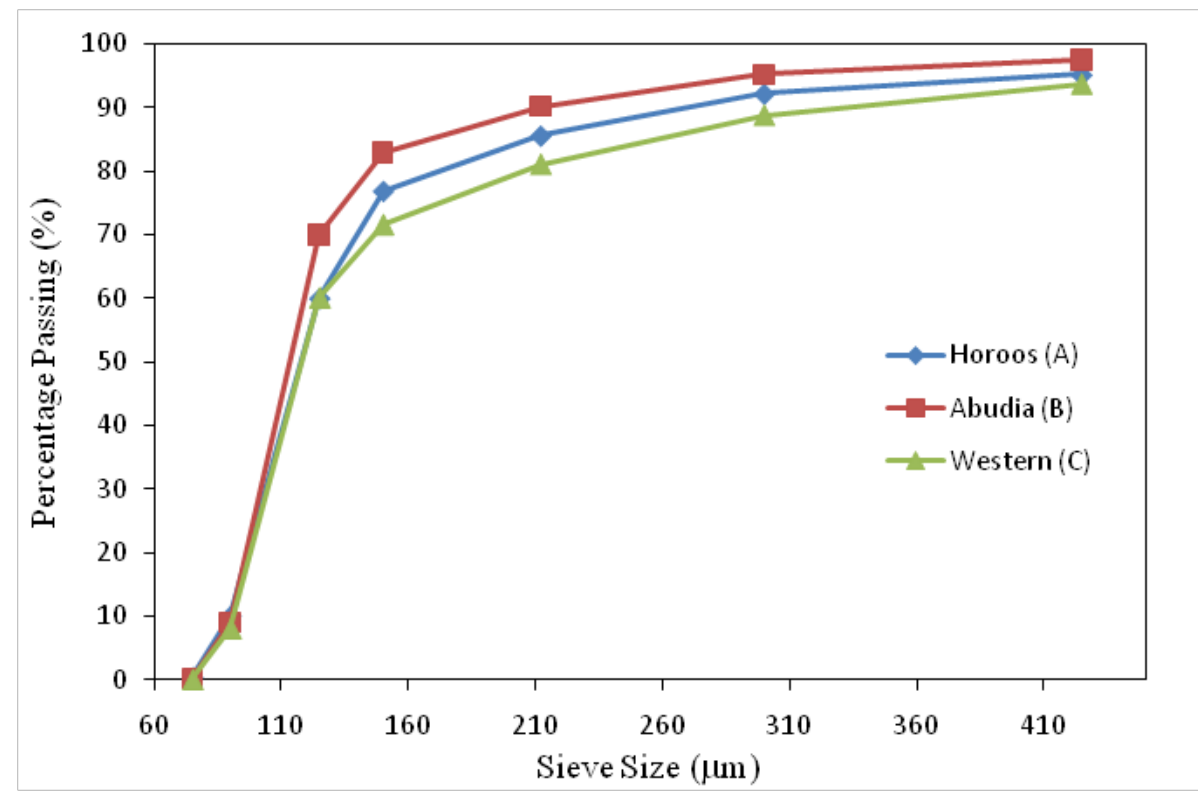

Fig. 2: Size distribution curves of slag samples.

\subsection{Chemical Composition}

The summary of the chemical composition of the slag samples investigated is shown in Table 1. The major constituents in the slag samples, determined by XRF, were $\mathrm{Na}_{2} \mathrm{O}, \mathrm{MgO}, \mathrm{Al}_{2} \mathrm{O}_{3}, \mathrm{SiO}_{2}$, $\mathrm{P}_{2} \mathrm{O}_{5}, \mathrm{~K}_{2} \mathrm{O}, \mathrm{CaO}, \mathrm{TiO}_{2}, \mathrm{MnO}$ and $\mathrm{Fe}_{2} \mathrm{O}_{3}$. The minor metal constituents are present as traces, with a concentration less than $16400 \mathrm{ppm}$. Trace elements determined include $\mathrm{V}, \mathrm{Cr}, \mathrm{Ba}, \mathrm{Co}, \mathrm{Ni}$, $\mathrm{Cu}, \mathrm{Zn}, \mathrm{Ga}, \mathrm{As}, \mathrm{Rb}, \mathrm{Sr}, \mathrm{Y}, \mathrm{Zr}, \mathrm{Nb}, \mathrm{Mo}$, Sn, Sb, Cs, La, Ce, Hf, Ta, Pb, Bi and U. There were variations in the chemical composition of the three samples investigated. Sample $\mathrm{B}$ had higher percent of major oxides $\left(\mathrm{Al}_{2} \mathrm{O}_{3}, \mathrm{SiO}_{2}, \mathrm{Na}_{2} \mathrm{O}, \mathrm{MgO}, \mathrm{K} 2 \mathrm{O}, \mathrm{CaO}\right)$ than samples $\mathrm{A}$ and $\mathrm{C}$. It was 
observed that, even for cupola furnace slag samples, there were strong variations in chemical composition. Sample A, for instance, had strong variations in $\mathrm{Na}_{2} \mathrm{O}$ (6.07\%), $\mathrm{Al}_{2} \mathrm{O}_{3}$ (12.76\%), and $\mathrm{Fe}_{2} \mathrm{O}_{3}$ (8.59\%) contents compared to sample B which had $15.90 \% \mathrm{Na}_{2} \mathrm{O}, 18.16 \% \mathrm{Al}_{2} \mathrm{O}_{3}$, and $3.67 \% \mathrm{Fe}_{2} \mathrm{O}_{3}$. The difference could be attributed to one or a combination of the following reasons: (1) contamination from refractory furnace linings, (2) quality and quantity of scraps charged into the furnace, (3) type and quantity of fluxing agent used and (4) type and quantity of coke used. Small and medium scale foundries in Ghana use different furnace charge ratios (coke:scraps:flux) without carrying out proper material balances. This results in reduced melting efficiency and therefore increasing generation of slag. High amount of $\mathrm{Fe}_{2} \mathrm{O}_{3}$ was recorded for induction furnace slag (sample $\mathrm{C}$ ). This is due to the slag removal technique which is by scooping or tilting of the furnace whilst in cupola furnaces, slag is allowed to flow through the slag spout. Table 1 also shows the loss on ignition (LOI) of the investigated samples. Sample A recorded the highest LOI of $18.20 \%$ followed by sample C (16.80\%) and sample B (3.80\%), respectively. Once again, the difference could be attributed to varied amount of furnace charge.

Table 1: Chemical compositions of investigated slag samples.

\begin{tabular}{|c|c|c|c|}
\hline Composition (\%) & A & B & $\mathrm{C}$ \\
\hline $\mathrm{Na}_{2} \mathrm{O}$ & 6.07 & 15.90 & 0.48 \\
\hline $\mathrm{MgO}$ & 1.31 & 2.00 & 1.68 \\
\hline $\mathrm{Al}_{2} \mathrm{O}_{3}$ & 12.76 & 18.16 & 8.45 \\
\hline $\mathrm{SiO}_{2}$ & 45.82 & 31.51 & 48.54 \\
\hline $\mathrm{P}_{2} \mathrm{O}_{3}$ & 0.09 & 0.09 & 0.06 \\
\hline $\mathrm{SO}_{3}$ & 0.59 & 0.45 & 0.37 \\
\hline $\mathrm{Cl}$ & 0.03 & 0.00 & 0.08 \\
\hline $\mathrm{K}_{2} \mathrm{O}$ & 0.27 & 0.41 & 0.32 \\
\hline $\mathrm{CaO}$ & 4.19 & 5.97 & 3.91 \\
\hline $\mathrm{TiO}_{2}$ & 0.55 & 0.47 & 2.82 \\
\hline $\mathrm{MnO}$ & 1.79 & 0.55 & 7.62 \\
\hline $\mathrm{Fe}_{2} \mathrm{O}_{3}$ & 8.59 & 3.67 & 25.89 \\
\hline LOI & 18.20 & 3.80 & 16.80 \\
\hline
\end{tabular}

\subsection{Mineralogical Composition}

XRD analysis was performed on the as-received samples. Figure 3 shows the XRD pattern for the investigated slags. The diffraction patterns were different for the three ferrous samples even though all slags are chemically similar in that their major components are $\mathrm{CaO}, \mathrm{SiO}_{2}, \mathrm{Al}_{2} \mathrm{O}_{3}$ and $\mathrm{MgO}$. All slag types were heterogeneous materials consisting of a mixture of complex crystalline phases. The analysis of the diffraction lines revealed the presence of the following major constituent phases: quartz $\left(\mathrm{SiO}_{2}\right)$, kyanite $\left(\mathrm{Al}_{2} \mathrm{SiO}_{5}\right)$, maghemite $\left(\gamma-\mathrm{Fe}_{2} \mathrm{O}_{3}\right)$, calcium iron oxide 
$\left(\mathrm{CaFe}_{4} \mathrm{O}_{7}\right)$, and kanoite (Mn, $\left.\mathrm{Mg}\right)_{2}\left(\mathrm{Si}_{2} \mathrm{O}_{6}\right)$. All slags investigated did not contain free $\mathrm{CaO}, \mathrm{MgO}$ and elemental iron. Iron present was in the form of an oxide or in solid solution. Any other minor constituent phases were very difficult to assign due to the complexity of the diffractograms, the low intensity of their diffraction lines as well as strong background signals.

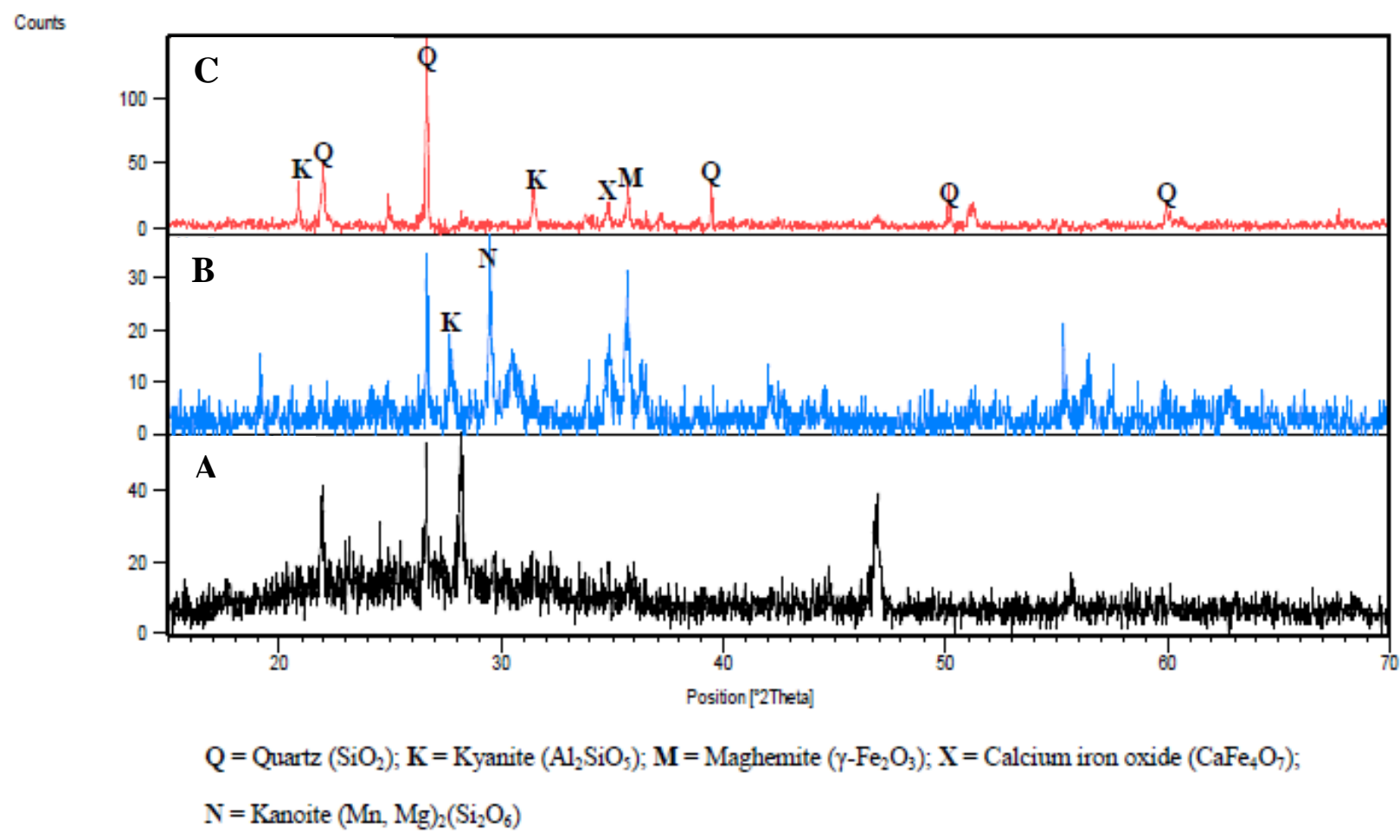

Fig. 3: XRD patterns of slag samples.

\subsection{Possible Industrial Utilization}

The amount of ferrous slags produced in foundry industries depends on the type of scraps, coke quality, and furnace efficiency among others [2-4,15]. Large amount of slag is produced when light scraps (rusted scraps) are used. Usually steel scraps produced the least amount of slag [16]. At Western Steel and Forging Limited, about 15 tons of slag is produced for every 100 tons of steel ingot produced. Small scale foundries produce about 5 tons of slag for every 30 tons of steel produced. It is interesting to note from this data that both small and medium scale foundries produce roughly the same amount of slag. As mentioned earlier, this is because of the complexity of various parameters that affect slag generation in the foundry operations. Unpublished data indicate that there are over 50 small and medium scale foundries scattered across Ghana. From our survey results, it is estimated that the amount of ferrous slag produced yearly is about 500,000 tons. The amount of slag generation in this industry would increase as foundrymen continue to charge rusted scraps, low quality furnace linings, and poor energy efficiency furnaces. 
Metallurgical slags have been used as raw materials for reclamation, cement production, road construction, floor tiles and fertilizers production, or soil conditioning [17-20]. The presence of major oxides like $\mathrm{CaO}, \mathrm{SiO}_{2}, \mathrm{FeO}$ and $\mathrm{Al}_{2} \mathrm{O}_{3}$ make metallurgical slag useful as clinker material in cement productions [21]. The clinker reduces the amount of energy used in the calcinations process because of the presence of free $\mathrm{CaO}$. It also reduces the amount of $\mathrm{CO}_{2}$ released into the atmosphere [22].

The mineralogical analysis indicated that the slag samples investigated had no free $\mathrm{CaO}$. For slag to be useful as raw material in cement production, it must meet certain requirements. In accordance with the European Standard (EN-197-1), slag to be used for cement production must have a minimum basicity ratio of 1 (i.e. $\left.(\mathrm{CaO}+\mathrm{MgO}): \mathrm{SiO}_{2} \geq 1\right)$. In practice, for technological reasons, the $\mathrm{Al}_{2} \mathrm{O}_{3}: \mathrm{Fe}_{2} \mathrm{O}_{3}$ ratio (must be $<1$ ), or so called hydraulic properties, expressed by the relationship ( $\left.\mathrm{CaO}+\mathrm{MgO}+\mathrm{Al}_{2} \mathrm{O}_{3}\right) / \mathrm{SiO}_{2}$ (must be $>1$ ) should also be known [7]. It is interesting to know that, even though the chemical composition of slags has complicated structures, they are usually expressed as if these compounds existed separately within the material. These oxide ratios have been calculated and tabulated in Table 2. In addition, slag to be utilized in the cement industry should contain the least possible contents of elements such as sodium, potassium, chlorine, chromium, as well as heavy metals and alkalis [7,20-22]. From Table 2, it is observed that the slag samples investigated had basicity ratios to be less than 1 which do not meet the requirement for use in clinker materials. Only sample $\mathrm{C}$ had $\mathrm{Al}_{2} \mathrm{O}_{3}: \mathrm{Fe}_{2} \mathrm{O}_{3}$ ratio to be less than 1 , however, the basicity ratio was also less than 1 and therefore does not also satisfy the requirement. The hydraulic properties of the investigated slags are also not satisfactory since the oxide ratios are less than 1 .

Table 2: Ratios of chemical composition of investigated slags.

\begin{tabular}{|c|c|c|c|c|}
\hline Slags & $\frac{\mathrm{SiO}_{2}}{\mathrm{Al}_{2} \mathrm{O}_{3}+\mathrm{Fe}_{2} \mathrm{O}_{3}}$ & $\frac{\mathrm{Al}_{2} \mathrm{O}_{3}}{\mathrm{Fe}_{2} \mathrm{O}_{3}}$ & $\frac{\mathrm{CaO}+\mathrm{MgO}^{2} \mathrm{Al}_{2} \mathrm{O}_{3}}{\mathrm{SiO}_{2}}$ & $\frac{\mathrm{CaO}+\mathrm{MgO}}{\mathrm{SiO}_{2}}$ \\
\hline $\bar{A}$ & 2.15 & 1.49 & 0.40 & 0.12 \\
\hline B & 1.44 & 4.95 & 0.83 & 0.25 \\
\hline C & 1.41 & 0.33 & 0.29 & 0.14 \\
\hline
\end{tabular}

The presence of free $\mathrm{CaO}$ and $\mathrm{MgO}$ in metallurgical slags is the reason why they are not used for road construction. It is believed that the presence of these oxides results in expansion of slags (about 10 vol. \%) under the influence of humidity hydrate [7,23,24]. When the presence of free $\mathrm{CaO}$ accounts for more than $1 \%$ increase in volume, another adverse property of steel slag, namely, the appearance of white powder in the form of sediment begins to form. Free $\mathrm{CaO}$ from the leachate bounds with water, creating calcium hydroxide, $\mathrm{Ca}(\mathrm{OH})$, which, when exposed to atmospheric conditions, reacts with carbon dioxide, creating calcium carbonate $\left(\mathrm{CaCO}_{3}\right)$ [23,24]. This settles down in the form of white powder and may cause obstructions in the drainage systems and water retention. Those obstructions are particularly dangerous in the case of 
freezing, which renders large damage to pavement structures [7]. The investigated slags do not have free $\mathrm{CaO}$ and $\mathrm{MgO}$ and therefore can be used for road bed construction.

Soil is generally acidic. Alkaline slags are used to amend soil acidity. Soil fertility is improved by the presence of $\mathrm{SiO}_{2}, \mathrm{MgO}$ and $\mathrm{FeO}$ in slag [25,26]. The $\mathrm{Ca}$ and $\mathrm{P}$ contents in alkaline slags make it a potential liming agent to increase the precipitation and sorption of metals such as $\mathrm{Cu}$ and a potential fertilizer promoting plant growth and improving physico-chemical properties of the soil. Slags investigated are alkaline and can therefore be used to amend soil $\mathrm{pH}$. It must however be mentioned that for effective results, the $\mathrm{CaO}, \mathrm{MgO}, \mathrm{FeO}$ and $\mathrm{SiO}_{2}$ contents in the slag be improved.

\section{CONCLUSION}

Chemical analyses of slag samples investigated showed varied composition as follows: $\mathrm{CaO} 3.91$ - 5.97\%, MgO 1.31 - 2.00\%, $\mathrm{Al}_{2} \mathrm{O}_{3} 8.45$ - 18.16\%, $\mathrm{SiO}_{2} 31.51$ - 48.54\%, $\mathrm{Na}_{2} \mathrm{O} 0.48$ - 15.90\%, $\mathrm{Fe}_{2} \mathrm{O}_{3} 3.67$ - 25.89\%, MnO 0.55 - 7.62\% and $\mathrm{K}_{2} \mathrm{O} 0.27-0.41 \%$. Ratios of oxide composition suggest that these slags cannot be used as clinker material for the production of Portland cement. From the chemical and mineralogical characterization results, it can be concluded that, cupola furnace slag and induction furnace slag generated in Ghana can only be useful as road bed material. However, $\mathrm{CaO}$ content must still be improved by addition of lime or proper slag mixing ratios for effective results. Slag samples are also alkaline and can therefore be used as soil fertility improver with slight modification in $\mathrm{CaO}$ content.

\section{REFERENCES}

[1] Ghosh, S., Das, M., Chakrabarti, S., Ghatak, S. 2002, Development of ceramic tiles from common clay and blast furnace slag. Ceram Int. 28, 393-400.

[2] Osipov, V.A., Timofeeva, Z.G., Kurbatskii, M.N., Mironova, P.V., Ocheretnyuk, F.F. 1990, Blast furnace granulated slag in the production of building ceramics. Glass Ceram. 47, 228-230.

[3] Dana, K., Das, S.K., 2004, Partial substitution of feldspar by blast furnace slag in triaxial porcelain: Phase and microstructural evolution. J. Euro. Ceram. Soc. 24, 3833-3839.

[4] Karamanova, E., Avdeev, G., Karamanov, A., 2011, Ceramics from blast furnace slag, kaolin and quartz, J. Euro. Ceram. Soc. 31, 989-998.

[5] Nistor, L., Cioroi, M., 2007, Recycling possibilities of metallurgical slag, The Annals of Dunarea DeJos, University of Galati, Fascicle IX, Metallurgy and Materials Science (1), 78-82.

[6] Fidancevska, E., Vassilev, V., Hristova-Vasileva, T., Milosevski, M., 2009, On a possibility for application of industrial wastes of metallurgical slag and TV-glass, J. Univ. Chem. Technol. \& Met. 44, 2, 189-196. 
[7] Navarro, C., Diaz, M., Villa-Gacia, M.A., 2010, Physico-chemical characterization of steel slag. Study of its behavior under simulated environmental conditions. Environ. Sci. Technol. 44, 5383-5388.

[8] Adygezalov, S.A., Dvortsov, S.P., Shemonaeva, T.N., Strakhov, V.M., Surovtseva, I.V., 2011, Industrial production of coke briquets for cupola smelting of iron, Coke \& Chemistry, 54 (1), 19-22.

[9] Diez, M.A., Alvarez, R., Barriocanal, C., 2002, Coal for metallurgical coke production: Prediction of coke quality and future requirements for coke making. Int. J. Coal Geol., Vol. 50, 289-412.

[10] Haley, D.G., 2004, The efficiency of coke producing quality iron from lower quality coke, www.asi-alloys.com/pdf/GeoHaleyCokePaper.pdf.

[11] Sarkar, R., Singh, N., Das, S.K., 2010, Utilization of steel melting electric arc furnace slag for development of vitreous ceramic tiles, Bull. Mater. Sci., 33 (3), 293-298.

[12] Skuza, Z., Kolmasiak, C., Prusak, R., 2009, Possibilities for the utilization of metallurgical slag in the conditions of polish economy, METABK, 48(2), 125-128.

[13] Barišić, I., Dimter, S., Netinger, I., 2010, Possibilities of application of slag in road construction, Technical Gazette, 17 (4), 523-528.

[14] Sofilić, T., Rastovčan-Mioč, A., Ćosić, M., Merle1, V., Mioč, B., Sofilić, U., 2011, EAF steel slag application possibilities in Croatia asphalt mixture production: http://www.aidic.it/CISAP4/webpapers/16Sofilic.pdf.

[15] Arkhipov, N.A., Gorokhov, V.L., 2003, New approaches to processing slags, Metallurgist, 47, (7-8).

[16] Tsakiridis, P.E., Papadimitriou, G.D., Tsivilis, S., Koroneos, C., 2008, Utilization of steel slag for Portland cement clinker production, J. Hazardous Mater., 152, 805-811.

[17] Alanyali, H., Col, M., Yılmaz, M., Karagoz, S., 2006, Application of magnetic separation to steelmaking slags for reclamation, Waste Management, 26, 1133-1139.

[18] Asi, I.M., Qasrawi, H.Y., Shalabi, F.I., 2007, Use of steel slag aggregate in asphalt concrete mixes, Can. J. Civ. Eng. 34, 902-911.

[19] Badiee, H., Maghsoudipour, A., Dehkordi, B.R., 2008, Use of Iranian steel slag for production of ceramic floor tiles, Advances in Applied Ceramics, 107 (2), 111-115.

[20] Qiang, W., Peiyu, Y., 2010, Hydration properties of basic oxygen furnace steel slag, Construction and Building Materials, 24, 1134-1140.

[21] Wang, G., 2010, Determination of the expansion force of coarse steel slag aggregate, Construction and Building Materials, 24, 1961-1966.

[22] Shi, C., 2004, Steel slag - Its production, processing, characteristics, and cementitious properties, J. Mater. Civil Eng., 231-236.

[23] Lewis, W.D., 2011, Properties and uses of iron and steel slags. http://www.nationaslagassoc.org.

[24] Song, L.K.M.R., Emery, S., 2001, Preliminary development of slag as a stabilized material for labor intensive construction of roads. Workshop on first international conference on employment creation on development, Univ. Witwatersrand, South Africa. 
[25] Alva, A.K., Sumner, M.E., 1990, Amelioration of acid soil infertility by phosphogypsum, Plant and Soil, 128 (2), 127-129.

[26] Carvalho-Pupatto, J.G., Bull, L.T., Crusciol, C.A.C., 2004, Soil chemical attributes, root growth and rice yield according to slag application, Pesquisa Agropecuaria Brasileria, 39 (12), 1213-1218. 